University of Nebraska - Lincoln

DigitalCommons@University of Nebraska - Lincoln

$2-2008$

\title{
Soil Modification by Invasive Plants: Effects on Native and Invasive Species of Mixed-Grass Prairies
}

\author{
Nicholas R. Jordan \\ University of Minnesota, St. Paul \\ Diane L. Larson \\ USGS Northern Prairie Wildlife Research Center, dlarson@usgs.gov \\ Sheri C. Huerd \\ University of Minnesota, St. Paul, huerd001@umn.edu
}

Follow this and additional works at: https://digitalcommons.unl.edu/usgsnpwrc

Part of the Other International and Area Studies Commons

Jordan, Nicholas R.; Larson, Diane L.; and Huerd, Sheri C., "Soil Modification by Invasive Plants: Effects on Native and Invasive Species of Mixed-Grass Prairies" (2008). USGS Northern Prairie Wildlife Research Center. 82.

https://digitalcommons.unl.edu/usgsnpwrc/82

This Article is brought to you for free and open access by the US Geological Survey at DigitalCommons@University of Nebraska - Lincoln. It has been accepted for inclusion in USGS Northern Prairie Wildlife Research Center by an authorized administrator of DigitalCommons@University of Nebraska - Lincoln. 


\title{
Soil modification by invasive plants: effects on native and invasive species of mixed-grass prairies
}

\author{
Nicholas R. Jordan · Diane L. Larson • \\ Sheri C. Huerd
}

Received: 4 August 2006/Accepted: 7 May 2007/Published online: 21 June 2007

(C) Springer Science+Business Media B.V. 2007

\begin{abstract}
Invasive plants are capable of modifying attributes of soil to facilitate further invasion by conspecifics and other invasive species. We assessed this capability in three important plant invaders of grasslands in the Great Plains region of North America: leafy spurge (Euphorbia esula), smooth brome (Bromus inermis) and crested wheatgrass (Agropyron cristatum). In a glasshouse, these three invasives or a group of native species were grown separately through three cycles of growth and soil conditioning in both steam-pasteurized and non-pasteurized soils, after which we assessed seedling growth in these soils. Two of the three invasive species, Bromus and Agropyron, exhibited significant self-facilitation via soil modification. Bromus and Agropyron also had significant facilitative effects on other invasives via soil modification, while Euphorbia had significant antagonistic effects on the other invasives. Both Agropyron and Euphorbia consistently suppressed growth of two of three native forbs, while three native grasses were generally less affected. Almost all intra- and interspecific effects of invasive soil conditioning were
\end{abstract}

N. R. Jordan $(\bowtie) \cdot$ S. C. Huerd

Department of Agronomy and Plant Genetics, University of Minnesota, 411 Borlaug Hall, 1991 Buford Circle, St. Paul, MN 55108, USA e-mail: jorda020@umn.edu

D. L. Larson

USGS Northern Prairie Wildlife Research Center, St. Paul, MN 55108, USA dependent upon presence of soil biota from field sites where these species were successful invaders. Overall, these results suggest that that invasive modification of soil microbiota can facilitate plant invasion directly or via 'cross-facilitation' of other invasive species, and moreover has potential to impede restoration of native communities after removal of an invasive species. However, certain native species that are relatively insensitive to altered soil biota (as we observed in the case of the forb Linum lewisii and the native grasses), may be valuable as 'nurse' species in restoration efforts.

Keywords Agropyron - Bromus - Euphorbia . Facilitation - Great Plains · Invasive plants . Mixed-grass prairie $\cdot$ Soil biota

\section{Introduction}

Recent evidence suggests that positive feedbacks between invasive plants and soils could contribute significantly to plant invasions (Corbin and D'Antonio 2004; Ehrenfeld 2004; Scott et al. 2001; Wolfe and Klironomos 2005; Reinhart and Callaway 2006; Eppstein and Molofsky 2007), perhaps exemplifying 'ecological engineering' by biological invaders (Cuddington and Hastings 2004). In the envisioned process, invasive species modify soils that they occupy in ways that increase their own fitness relative to that of native species. Positive feedback ensues if increased 
invasive fitness furthers the degree or extent of soil modification, in turn further favoring these invasives over natives.

There is much evidence that invasive plant species can modify physical or chemical attributes of soil, including inputs and cycling of nitrogen and other elements (Ehrenfeld 2003; Haubensak et al. 2004; Hawkes et al. 2005; Sperry et al. 2006), pH (Kourtev et al. 2003), and soil organic matter and aggregation (Saggar et al. 1999). There is also evidence of direct modification of various components of the biotic composition of invaded soil, e.g., affecting a soil food web (Duda et al. 2003), total soil microbial communities (Kourtev et al. 2002a, b; Kourtev et al. 2003), and mutualistic fungi (Allen et al. 2003; Hawkes et al 2006; Mummey and Rillig 2006).

As noted, these effects will enable plant invasion by positive feedback with soil attributes only if invasive species are benefited, and indeed there are clear indications of such benefits.. In temperate old-field communities, modification of soil microbiota by common invasive species typically had beneficial or neutral effects on growth of these species (Klironomos 2002; Agrawal et al. 2005) and microbiota associated with roots of several invasive woody species have increased growth of these species (Bray et al. 2003; Reinhart et al. 2003). However, evidence is sparser on a crucial issuewhether these effects benefit invasive species more than natives. In competition with native species, the relative performance of the invasive perennial herb Centaurea melitensis was much increased by the presence of soil fungi (Callaway et al. 2003) and an experimentally imposed period of soil modification by the related $C$. maculosa had a similar effect (Reinhart and Callaway 2006). In non-experimental studies in several plant communities, soil biota from stands dominated by certain invasive species were found to reduce growth of several native species (Allen et al. 2003; Yu et al. 2005; Stinson et al. 2006). Also, invasive modification of soil nitrogen cycling has been associated with reduced native growth and abundance (Haubensak et al. 2004; Symstad 2004). Both findings are indicative of selffacilitative soil modification by invasives, but additional experimental analyses are certainly needed. It is also necessary to assess the effects of soil modification by invasives on the general invasibility of plant communities. For example, if soil modification by invasives can facilitate other invasives and exert harmful effects on native species, then soil modification effects may contribute to an 'invasional meltdown' process (Simberloff 2006).

The experiments reported below assess self-facilitative effects of soil conditioning by three highlyinvasive species in grasslands of the northern Great Plains of North America, and also examine the following questions concerning general community invasibility: (1) Can soil conditioning by one invasive species increase fitness of others, thus increasing community invasibility by a 'cross facilitation' process that promotes invasion by multiple species? (2) Does invasive soil conditioning have uniformly damaging effects on native species within a community, or are fitness effects variable?

In the experiments reported below, we estimated effects of soil conditioning by smooth brome (Bromus inermis Leyss.; hereafter Bromus), crested wheatgrass (Agropyron cristatum (L.) Gaertn; hereafter Agropyron), and leafy spurge (Euphorbia esula L.; hereafter Euphorbia). All three of these species are 'strong invaders' (Ortega and Pearson 2005), able to become community dominants and to form nearly monospecific stands, and therefore we were particularly concerned with the effects of soil conditioning by these species on prospects for native restoration or reinvasion by other invasive species. In each of three separate experiments, a single invasive species was grown for three cycles of glasshouse growth and vernalization, in a growth medium inoculated with soil from a field site where that particular species has invaded and established extensive stands. A mixture of native species was also grown for three such cycles, for comparative purposes. We used a mixture of native species to better simulate the conditions found in the field, since native species in mixed-grass prairie typically grow in diverse assemblages, rather than the monocultures found for invasive species. After these periods of soil conditioning, seedling biomass production by all three invasives and six native species was assessed in each experiment, and used to estimate self-facilitation by invasives, and facilitative or antagonistic effects on other species.

\section{Materials and methods}

Study species and field sites

In natural areas of the mixed-grass prairies of the Dakotas and eastern Montana (USA), Bromus and 
Agropyron characteristically grow in nearly monocultural stands and defy managers' attempts at control and restoration of native vegetation (Bakker et al. 1997; Blankespoor and May 1996; Christian and Wilson 1999; Grilz and Romo 1995; Nernberg and Dale 1997). Although both of these sod-forming cool season grasses were originally planted for livestock forage, they readily invade native prairie sod (Heidinga and Wilson 2002; Henderson and Naeth 2005). Agropyron degrades prairie soils, apparently because of low root:shoot allocation, reducing carbon and nitrogen levels relative to similar soils under successional prairie (Christian and Wilson 1999).

A third invasive species of considerable importance in the northern Great Plains is Euphorbia. Density can reach $100 \%$ of biomass in severe infestations (D. Larson, unpublished data). This species is unpalatable to most domestic and native ungulates (Trammell and Butler 1995) and thus reduces carrying capacity of both rangeland and natural areas. Herbicides and biological control have been used with varying success, but revegetation of controlled sites by native plants is often slow (Butler et al. 2006; D. Larson and S. Huerd, personal observation), providing the opportunity for Euphorbia reinvasion or invasion by other weedy species.

Soils were gathered from each of three nature reserves. In each reserve, a particular invasive species was especially problematic, although all reserves are located within the North American range of all three invasive species. Soils were sampled in each reserve from sites occupied by the problematic species. Thus, Bromus sites were sampled at Lostwood National Wildlife Refuge, ND, USA ( $\left.48^{\circ} 34^{\prime} \mathrm{N}, 102^{\circ} 26^{\prime} \mathrm{W}\right)$; Agropyron sites were sampled at Medicine Lake National Wildlife Refuge, MT, $\left(48^{\circ} 25^{\prime} \mathrm{N}\right.$, $\left.104^{\circ} 26^{\prime} \mathrm{W}\right)$; and Euphorbia sites were sampled at Theodore Roosevelt National Park, ND, $\left(46^{\circ} 59^{\prime} \mathrm{N}\right.$, $\left.103^{\circ} 33^{\prime} \mathrm{W}\right)$. At each reserve, 151 of soil were taken from the upper $20 \mathrm{~cm}$ of soil from each of three sets of paired sampling sites. Each pair of sampled sites was comprised of a site heavily occupied by an invasive species, and a nearby site (within $50 \mathrm{~m}$ ) largely occupied by native species. Sampled soils from each site type (invaded or native-occupied) within a reserve were kept cool and moist, sieved of coarse debrix, and mixed together for use in glasshouse experiments below. Soils harvested from Lostwood NWR and Medicine Lake NWR were
Typic Argiustolls, mainly loam/sandy loam in texture; soils from Theodore Roosevelt National Park were Aridic Ustorhents, mainly loam, clay loam or sandy loam.

\section{Glasshouse experiments}

Experiments were conducted in a glasshouse on the University of Minnesota campus, St. Paul, MN from September 2002 to November 2003. At the inception of the experiment, half of each field soil sample was steam-pasteurized twice, $24 \mathrm{~h}$ apart (40 $\mathrm{min}$ at $80^{\circ} \mathrm{C}+20 \mathrm{~min}$ aeration to mitigate $\mathrm{N}$ accumulation; modified from Burrows and Pfleger (2002); referred to as 'sterilized' henceforth) to kill all soil biota. From each site type, a soil sample was taken from the bulk soil and analyzed for chemical composition at the University of Minnesota Soil Testing Laboratory (St. Paul, MN, USA) before and after pasteurization. No significant changes in soil $\mathrm{pH}, \mathrm{P}, \mathrm{K}$, and $\mathrm{N}$ were observed. To prepare an experimental growth medium, field soils (either sterilized or unsterilized 'live' soil) were mixed with an equal amount of pasteurized sand. Plants were grown in pots $(15 \mathrm{~cm}$ diameter) for four growing periods separated by vernalization periods (see schedule below), during which the plants were held at $4{ }^{\circ} \mathrm{C}$ in a dark refrigerated chamber. The first three growth periods were used to enable any effects of soil conditioning by the invasive species to accrue over time. In the fourth growth period, both natives and invasives were sown in each pot to assess seedling biomass production. Seeds of invasive species were collected at sites of soil collection; seeds of native species were purchased (Prairie Mountain Roots, Arcola, Saskatchewan, Canada). Native species used in the experiment were selected from a list of species common to the northern mixedgrass prairie and the vegetation types from which we sampled, and were found at sites where we sampled. For the first three growth cycles, pots were sown either with a single invasive plant species (Euphorbia, Bromus or Agropyron) or a mixture of native plant species. Native mixtures varied somewhat among the three initial growth periods, due to changes in seed availability. Period 1 species were Aster ericoides L., Bouteloua gracilis (Willd. Ex Kunth) Lag. ex Griffiths, Stipa viridula Trin; Period 2: A. ericoides, B. gracilis, S. viridula, Liatris ligulistylis (A. Nels.) K. Schum., Koeleria macrantha 
(Ledeb.) J.A. Schultes; Period 3: A. ericoides, B. gracilis, S. viridula L. ligulistylis, Linum lewisii Pursh., K. macrantha, Muhlenbergia cuspidata (Torr. ex Hook.) Rydb., Ratibida columnifera (Nutt.) Woot. \& Standl., Stipa comata Trin. \& Rupr., (nomenclature according to plants.usda.gov visited 7/28/06).

As noted, three separate experiments were conducted; each used soils from just one of the three nature reserves (i.e., soil collection sites). The invasive species associated with sampled soils from a given reserve was repeatedly grown in soils from that reserve (i.e., Bromus in soils from Lostwood NWR, etc.). These three experiments occurred simultaneously and on adjacent glasshouse benches, with no intermingling. In each growth period, the same native species mixture was used in all three experiments. Each experiment used an identical randomized complete block design, with 16 replicates and 8 treatments. Treatments were a factorial combination of soil origin types (originally invasive- or native-occupied at time of collection in field), soil conditioning treatments (invasive or native mixture) and soil types (sterilized or unsterilized). These experiments took place in a single naturally lit glasshouse, with 400 watt highpressure sodium lamps used for supplemental lighting (14-16 h) from Sept. to May. Average summer glasshouse temperatures were $27: 23^{\circ} \mathrm{C}$ (day:night); spring and fall temperatures were $21: 19^{\circ} \mathrm{C}$. Plants were watered daily. Pots were fertilized once in each of the first 3 rounds of growth as follows: Round 1:50 $\mu \mathrm{g} / \mathrm{g}$ 25N-0P-25K; Round 2:10 $\mu \mathrm{g} / \mathrm{g}$ 21N-7P-7K; Round 3:50 $\mu \mathrm{g} / \mathrm{g}$ ammomium nitrate.

After each growth period, aboveground biomass was clipped. After vernalization periods as noted below, pots were placed back in the glasshouse and re-seeded with the native seed mixture or the appropriate invasive species; thus, plant biomass in successive growth periods was comprised of a moderate amount of regrowth from perenniating structures remaining in the soil and newly emerged seedlings. The initial three growth periods occurred during 27 Sept.-26 Nov. 2002, 19 Feb.-14 May 2003, and 24 June-9 Sept. 2003, respectively, with vernalization during the interim periods. In the final growth period (24 Sept-5 Nov 2003), each pot was planted with Bromus, Agropyron, and Euphorbia and six native species (A. ericoides, B. gracilis, K. macrantha, L. lewisii, R. columnifera, S. viridula). Species were planted in a specific pattern, used in each pot. Regrowth from perenniating structures remaining in the soil was clearly distinguishable from emerging seedlings; this regrowth was promptly removed when visible above the soil surface. After 6 weeks of growth, plants were counted and clipped by species/ pot, dried and weighed; at this time, seedlings of each species were small and well-separated from other species in each pot, and were assumed not to interact with other seedlings. We did not collect belowground biomass.

By comparing seedling biomass production in pots originally containing unsterilized or sterilized soil, we sought to assess the effects of invasive soil conditioning (the issue of primary interest in our study) in the presence of soil microbiota indigenous to sites where each species had invaded extensively, and in the absence of these particular soil biota. Undoubtedly, during the three glasshouse growth/ vernalization cycles, various soil organisms colonized pots that initially received sterilized soil. However, we believe that there was relatively little colonization of these pots by soil biota from pots receiving unsterilized inoculum soil, based on two lines of evidence. First, in a subsequent experiment using identical protocols (Jordan et al., unpublished data), we found very low rates $(<3 \%)$ of root colonization by arbuscular-mycorrhizal fungi in these pots, while high rates (13-88\%) were observed in pots established with unsterilized soil. Second, we observed very little among-replicate variation in growth of certain native forbs (A. ericoides and $R$. columnifera). These species consistently produced very little biomass in pots initially receiving sterilized soil, while pots receiving unsterilized soil were substantially more productive. The consistently poor growth of these species in sterilized soil argues against variable colonization of these pots by any soil biota capable of significantly affecting the growth of these species. Further, we have no reason to believe that ambient microbiota in the glasshouse environment differentially colonized the sterilized and unsterilized soils. On the basis of these observations and the mycorrhizal colonization data, we interpreted the 'sterilized inoculum' treatment as reflecting effects of a limited number of soil biota that colonized these pots during the three glasshouse growth cycles. 
Statistical methods

We used the General Linear Models procedure in SAS Version 8 (SAS Institute 1999) to partition effects of soil origin (collected at an invaded site or a native-dominated site), soil inoculum treatment (sterilized or unsterilized), and conditioning treatment (invasive or native) and their interactions on seedling plant biomass. Our analysis focused on preplanned comparisons between mean seedling biomass in soils receiving live field inocula and conditioned either by an invasive species ('I+' soils) or by the native-species mixture ('N+' soils). When mean seedling biomass in I+ soils differed significantly from mean biomass in $\mathrm{N}+$ soils, we inferred an effect (facilitative or antagonistic) of soil conditioning by that invasive species. As noted above, experimental units receiving sterilized inocula doubtless did not remain sterile over the duration of the experiment. Therefore, when there was a significant interaction between effects of soil 'sterilization' and soil conditioning treatments, we inferred that soil biota derived from field inocula affected the outcome of soil conditioning differently than did soil biota colonizing sterilized-inocula experimental units in the glasshouse, i.e., that soil microbiota played a mediating role in observed soil conditioning effects. Means were compared using Fisher's LSD. All significance tests were conducted at the $P=0.05$ level.

\section{Results}

Effects of soil conditioning treatments typically overwhelmed any effects of vegetation occupying soils at time of field collection, and/or of associated biophysical factors operant at field sites. Significant interaction effects involving soil origin (i.e., initial collection from native- or invasive-dominated sites) occurred in only three of 27 instances (i.e., nine species in soil from three reserves), and no pattern was evident among these three. Therefore, subsequent analyses combined results of the two soil origins for each sterilization by conditioning treatment; this leaves four treatments, instead of eight, in each experiment. ANOVA tables are reported in Appendix 1.
Soil conditioning by invasive species: effects on invasives

We observed two instances of direct self-facilitation over the time-scale of the experiment, in Agropyron and Bromus, among the three invasive species (Figs. 1b, 2c). In both cases, self-facilitation occurred only in pots receiving unsterilized inoculum; neither species showed substantial or significant self-facilitation in pots receiving sterilized inoculum. Thus, self-facilitation by Agropyron and Bromus was dependent on the presence of soil biota indigenous to the Medicine Lake and Lostwood sites, respectively. Our results suggest that both Agropyron and Bromus modified soil microbiota present at soil collection over several cycles of growth, and that resultant microbiota increased seedling growth of both invasives relative to that observed in response to microbiota associated with native species. We note that microbiota resulting from association with Agropyron had, in net effect, a small parasitic effect on that species $(\mathrm{I}+<\mathrm{I}-$, Fig. 1b), but, crucially, this parasitic effect is much smaller than exerted by native-associated microbiota $(\mathrm{N}+<<\mathrm{N}-$, Fig. 1b). Therefore, Agropyron has a self-facilitative effect on soil microbiota over the time-scale of the experiment.

We also observed several instances of interspecific 'cross-facilitation' among invasives. Soil conditioning by Agropyron facilitated Bromus seedling growth (Fig. 1c), while Bromus had a facilitative effect on Euphorbia (Fig. 2a). As was true for self-facilitation, both interspecific effects occurred only in unsterilized-inoculum treatments and thus again were apparently dependent on soil biota from the Medicine Lake and Lostwood sites, respectively. In the absence of these soil biota, interspecific effects were negative (Figs. 1c, 2a), with significant heterogeneity between the effects of conditioning and soil-inoculum treatments in both cases. Therefore, soil biota from the sites of invasion appeared to mediate a facilitative interspecific effect, while corresponding effects in the absence of these biota were antagonistic or neutral (Agropyron effect on Bromus Fig. 1c and Bromus effect on Euphorbia Fig. 2a, respectively). Euphorbia had no interspecific facilitative effects in unsterilized soil treatments, but did have significant facilitative effects on both Agropyron and Bromus in the sterilized-soil treatment (Fig. 3b, c). 

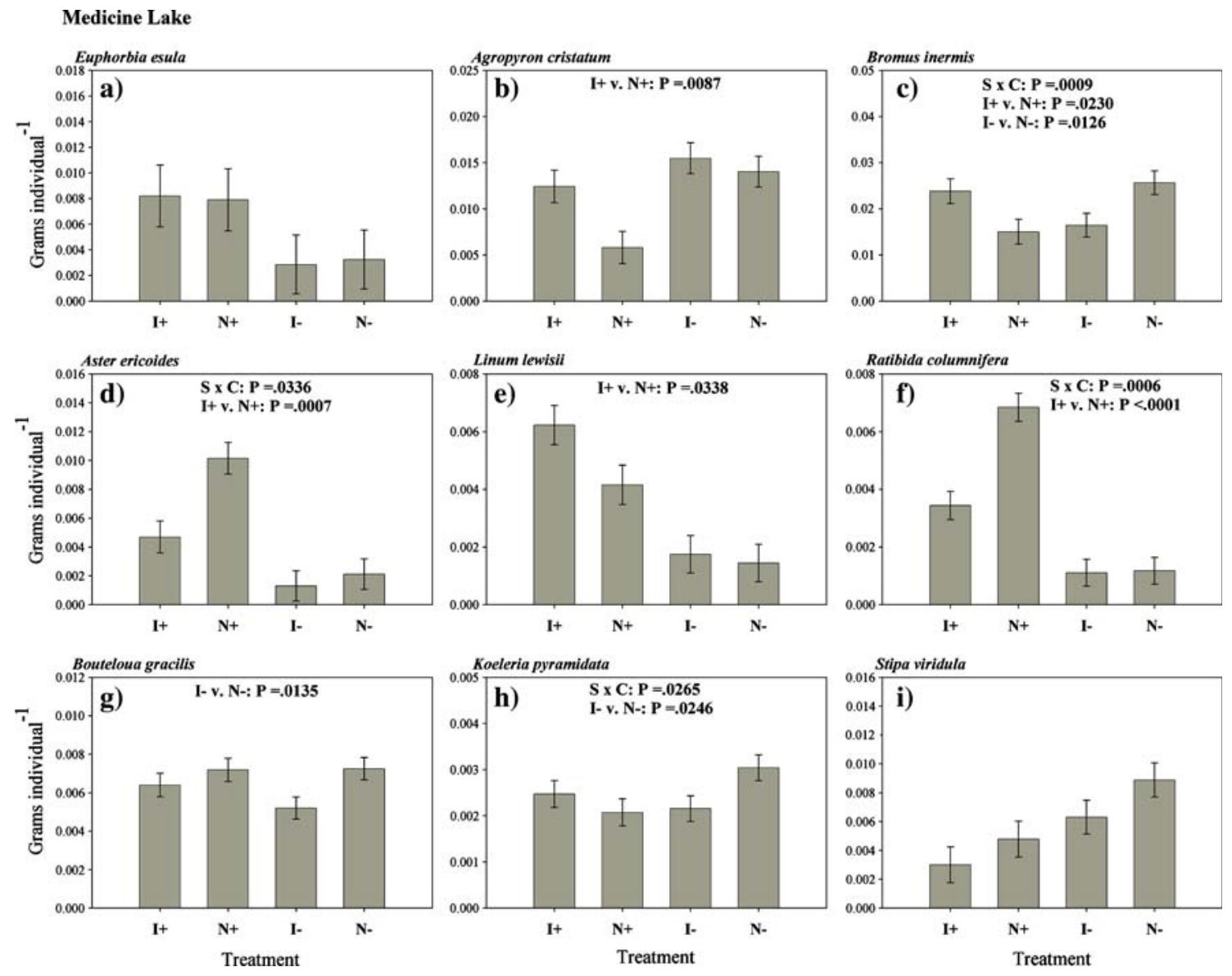

Fig. 1 Seedling biomass of invasive and native species in response to soil conditioning (C) and sterilization (S) treatments; soils were collected at Medicine Lake NWR, MT and conditioned by Agropyron or native species. $\mathrm{I}^{+}=$invasive conditioning with unsterilized soil; $\mathrm{I}^{-}=$invasive conditioning with sterilized soil; $\mathrm{N}^{+}=$native conditioning

Soil conditioning by invasive species: effects on natives

Each invasive species had strongly antagonistic effects on at least two of the three native forbs. Soil conditioning by Agropyron sharply reduced growth of Aster and Ratibida and Bromus had antagonistic effects on Linum and Ratibida (Figs. 1d, f, 2e, f, respectively). Soil conditioning by Euphorbia resulted in reduced growth of all three forb species (Fig. 3e-f). In all cases, antagonistic effects occurred only in pots receiving unsterilized soil; none of the invasive species had antagonistic effects in pots receiving sterilized soil, where the forbs generally with unsterilized soil; $\mathrm{N}^{-}=$native conditioning with sterilized soil. $\mathrm{S} \times \mathrm{C}$ denotes significance level of ANOVA interaction of conditioning and inoculum treatment factors; $\mathrm{I}^{+}$ vs. $\mathrm{N}^{+}$and $\mathrm{I}^{-}$vs. $\mathrm{N}^{-}$denote significance levels of preplanned comparisons. Shown are least square means and standard errors

failed to thrive. Thus, these antagonistic effects on native species appear to have been mediated by soil biota indigenous to the Medicine Lake, Lostwood, and Theodore Roosevelt NP sites, respectively. All effects of invasive soil conditioning on native forbs were antagonistic, with one exception: conditioning by Agropyron increased Linum growth, and this effect occurred only in the unsterilized-inoculum treatment (Fig. 1e).

In comparison to effects on the native forbs, effects on the native grasses were weaker and more variable. Four of five significant effects involved sterilized inocula. Agropyron conditioned soil was antagonistic to growth of Bouteloua and Koeleria 

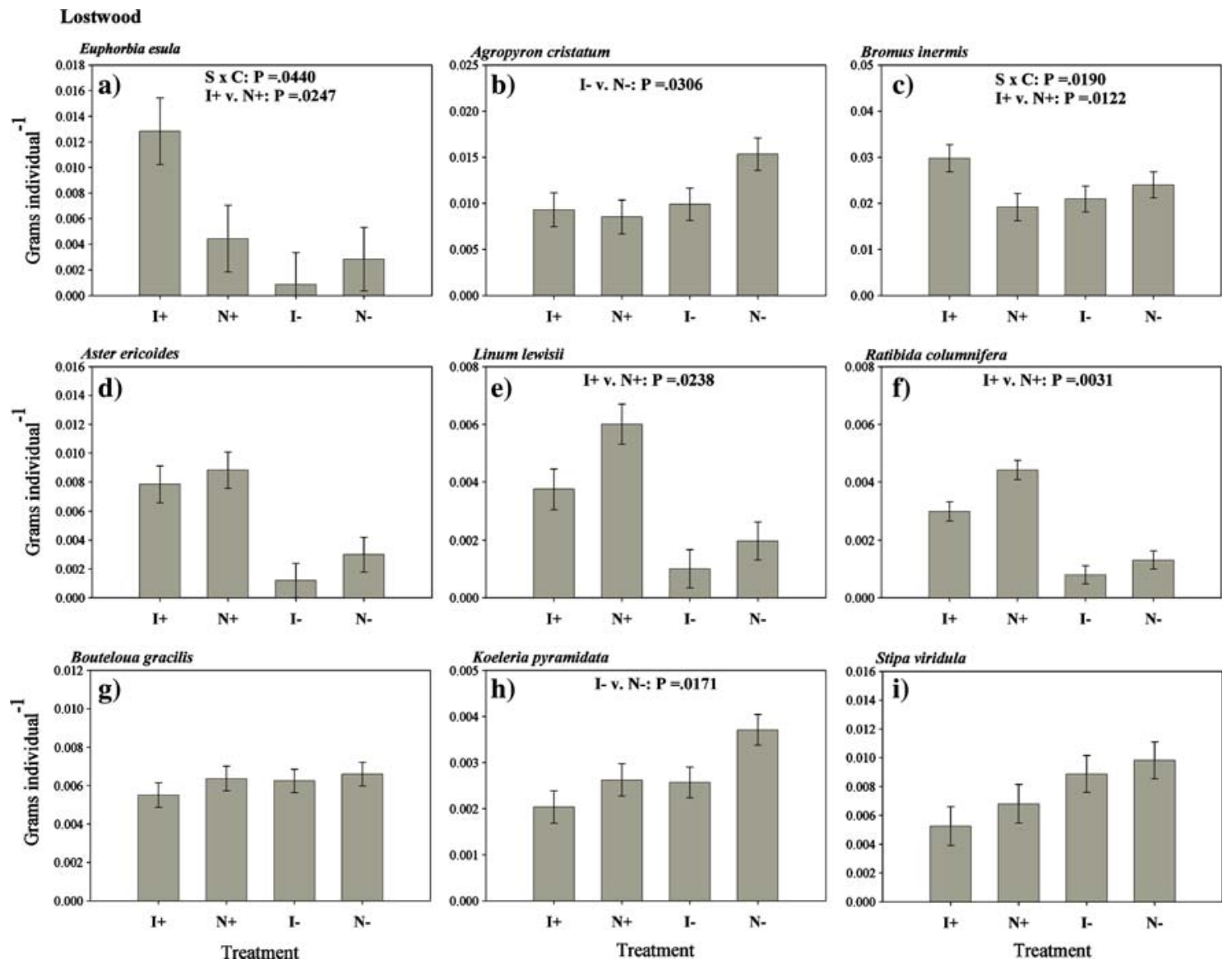

Fig. 2 Seedling biomass of invasive and native species in response to soil conditioning (C) and inoculum (S) treatments; soils were collected at Lostwood NWR, ND and conditioned by Bromus or native species. $\mathrm{I}^{+}=$invasive conditioning with unsterilized soil; $\mathrm{I}^{-}=$invasive conditioning with sterilized soil; $\mathrm{N}^{+}=$native conditioning with

(Fig. 1g, h). Apparently, the Medicine Lake soil biota mediated a facilitative effect of Agropyron conditioning on these two grasses that overrode the antagonistic effects observed in the absence of these soil biota. Similarly, Bromus had a negative effect on Koeleria growth (Fig. 2h) in sterilized inoculum. Euphorbia had a positive effect on Bouteloua (Fig. 3g). Only Euphorbia had an effect on any native grass species in an unsterilized-inoculum treatment: a negative effect on Koeleria (Fig. 3h). As for the invasive grasses, this pattern of Euphorbia effects on native grasses suggests that soil biota from the Theodore Roosevelt NP site mediated negative effects of Euphorbia. Apparently these negative effects overrode more positive effects exerted by unsterilized soil; $\mathrm{N}^{-}=$native conditioning with sterilized soil. $\mathrm{S} \times \mathrm{C}$ denotes significance level of ANOVA interaction of conditioning and inoculum treatment factors; $\mathrm{I}^{+}$vs. $\mathrm{N}^{+}$ and $\mathrm{I}^{-}$vs. $\mathrm{N}^{-}$denote significance levels of preplanned comparisons. Shown are least square means and standard errors

Euphorbia on all three native grasses in sterilizedinoculum treatments.

\section{Discussion}

Plant-soil feedback may facilitate plant invasion

Two of three invasive species exhibited significant self-facilitation, and we found significant cross-facilitation for Bromus in Agropyron-conditioned soils and for Euphorbia in Bromus-conditioned soils. Most of these effects were contingent on presence of unsterilized inoculum, containing live soil biota from field sites. We note that our results address only the 

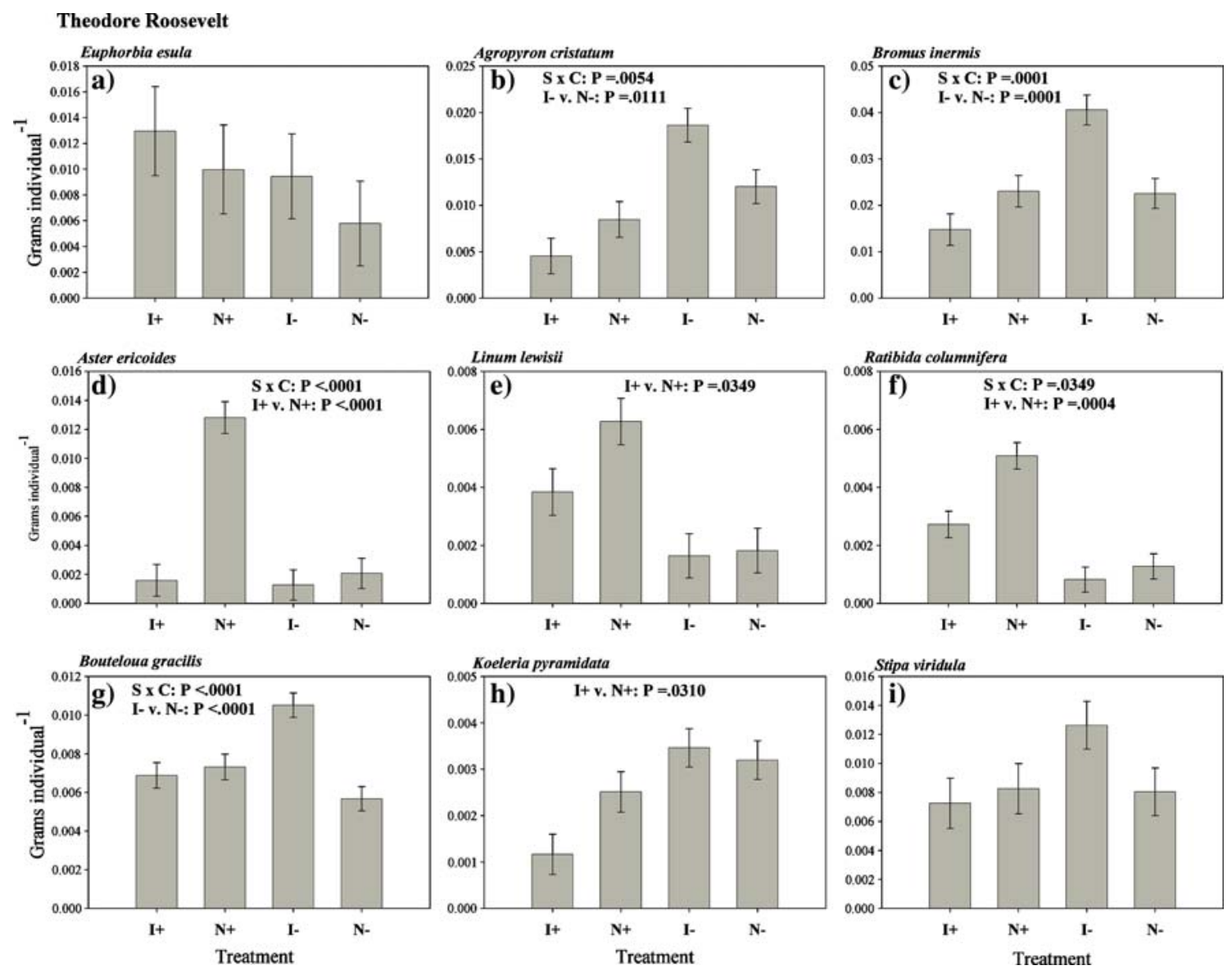

Fig. 3 Seedling biomass of invasive and native species in response to soil conditioning (C) and inoculum (S) treatments; soils were collected at Theodore Roosevelt National Park and conditioned by Euphorbia or native species. $\mathrm{I}^{+}=$invasive conditioning with unsterilized soil; $\mathrm{I}^{-}=$invasive conditioning with sterilized soil; $\mathrm{N}^{+}=$native conditioning

establishment phases of grassland perennial plant species and thus examine only one component of their fitness; however, establishment may be a strongly limiting phase for grassland perennials (van der Heijden 2004). With that caveat, our findings implicate soil biota in the mechanisms by which facilitative and antagonistic effects operated in these experiments, and support the hypothesis that plant invasion can be promoted by positive feedback mediated by living components of soil. In fact, soil biota are likely to play mediating roles in most of the soil-modifying effects presently attributed to invasive plant species, including alterations to biogeochemical cycling and soil organic matter and aggregation (Saggar et al. 1999). with unsterilized soil; $\mathrm{N}^{-}=$native conditioning with sterilized soil. $\mathrm{S} \times \mathrm{C}$ denotes significance level of ANOVA interaction of conditioning and inoculum treatment factors; $\mathrm{I}^{+}$ vs. $\mathrm{N}^{+}$and $\mathrm{I}^{-}$vs. $\mathrm{N}^{-}$denote significance levels of preplanned comparisons. Shown are least square means and standard errors

Soil biota may also play crucial mechanistic roles when invasive species directly modify various soil biota. While we did not use descriptive methods such as phospholipic fatty acid analysis to examine dynamics in soil biotic communities in the experiments reported above, there is abundant evidence that invasive species do modify soil biotic communities (e.g., Duda et al. 2003; Kourtev et al. 2003; Hawkes et al. 2006). Our findings of self-facilitation that appear to be mediated by soil biota affirm results from previous assessments of actual or potential selffacilitative feedbacks between invasive plants and soil biota, which have inferred substantial positive feedbacks in most cases (Reinhart and Callaway 2006). 
In contrast, we are not aware of previous reports of interspecific facilitation among invasive species mediated through any soil-related mechanism, although interspecific facilitation is well known among plants (Bertness and Callaway 1994), and efforts have been made recently to integrate facilitation into conceptual models of plant communities (Lortie et al. 2004). Our findings, along with other, more indirect lines of evidence suggesting such 'cross-facilitation' among invasives (Carino and Daehler 2002; Haubensak et al. 2004; Symstad 2004), lend support to a more generalized model of plant invasion by plant-soil feedback, in which invasives transform soil attributes such that native species are broadly disadvantaged relative to a set of invasives. The implication is that plant invasion could be driven by what are, in effect, multispecies mutualisms among invasive species and soil biota (Stanton 2003) as well as pair-wise mutualism (Simberloff and Von Holle 1999). For example, soil modification by Agropyron had neutral effects on Euphorbia and positive effects on Bromus, while the native forbs, Aster and Ratibida, both grew poorly in Agropyron-conditioned soil. This pattern of results is consistent with an indirect facilitative effect of Agropyron on the other two invasives, in which Agropyron benefits the invasives by exerting a negative effect on the two natives. In this way, strong antagonism toward native species can convert neutral or weakly antagonistic inter-invasive effects into net facilitation, if other native species respond similarly to the ones tested in this experiment.

We emphasize that interspecific inhibitory effects were also observed among the invasive species, in particular with respect to effects of Euphorbia on other grass species. Neither of the invasive grass species had significant negative biotic effects on other grasses or on Euphorbia, suggesting properties peculiar to Euphorbia that, mediated by soil biota, negatively affect a broad range of plant species. While Euphorbia did not demonstrate significant direct self-facilitation, its strong negative biotic effects on most other species constitute an indirect form of self-facilitation. Finally, we note that microbial-mediated intra- or inter-specific facilitative effects have yet to be assessed relative to other factors, such as nutrient supply (Pywell 2002; Walker et al. 2004) or recurrent disturbance known to strongly affect plant invasion generally, and such comparative assessments are now much needed to elucidate the importance of interactions between invasives and soil microbes in plant invasion.

Invasive-conditioning effects on native species

Our findings also add to a smaller base of evidence supporting the hypothesis that modification of soil biota by invasive plants facilitates their invasion by reducing native fitness (Reinhart and Callaway 2006). These antagonistic effects of invasives on natives, mediated by soil biota, represent a little-recognized but potentially powerful mechanism of plant interference. Our results show that the three forbs generally (seven of nine cases) grew well only in the presence of field biota from soils conditioned by a mixture of native species, suggesting establishment and regeneration of these species is highly dependent on suitable soil biota. This inference is supported by previous work establishing that seedling growth of most of these species was reliant on arbuscular-mycorrhizal fungi (Wilson and Hartnett 1998). Such species would appear to be especially vulnerable to biotic modifications caused by invading species. More broadly, there are indications that native tallgrass prairie plant species develop species-specific rhizosphere soil microbiota (L. Kinkel, personal communication), similar observations have been made in other plant communities (e.g., Westover et al. 1997). If species-specific soil biota are important to the ecology of these native species at a variety of phenological and life-cycle phases, then invading species may gain a substantial advantage if they are able to degrade native-associated biota through soil modification. Clearly, such antagonism toward natives might increase niche opportunities (Shea and Chesson 2002) available to invasive species by decreasing resource competition and other forms of interference from natives. Indeed, survey data from Theodore Roosevelt National Park (Larson et al. 2001) indicate significant negative associations in the field between Euphorbia and the native forbs and grasses used in the present experiment (Aster, Ratibida, and Bouteloua had significant negative correlations with Euphorbia abundance within infested vegetation types, Linum, Koeleria and Stipa had non-significant negative associations with Euphorbia; Larson, unpublished data).

Overall, we found that soil microbiota appeared to mediate facilitative effects within and among invasive species and antagonistic effects of some 
invasives on some natives. These effects suggest additional mechanisms by which soil biota can promote plant invasion, in addition to the soilpathogen version of the enemy-escape hypothesis (Callaway et al. 2004a; van der Putten et al. 2005; Agrawal 2005; Hallett 2006), which holds that escape from natural enemies facilitates invasion, and which is supported by a number of experimental studies (Reinhart and Callaway 2006). In principle, invasive self- and cross-facilitation by positive feedback with mutualistic soil microbiota (Callaway 2003) can work together with enemy-escape effects to increase niche opportunity (Shea and Chesson 2002) for invasives, and thus to further increase invasibility of invaded plant communities. This multiplicity of mechanisms suggests that soil microbes may promote plant invasions in powerful and complex ways.

\section{Conservation implications}

We did not find that biotic soil modification by invasive species had uniformly negative effects on native species, suggesting the potential for "strategic" restoration plans in which native species that are tolerant to the invasive conditioned soil are initially planted after removal of the invasive, to prepare the soil for less tolerant species. For example, invasive conditioning typically had milder inhibitory effects on native grasses than on native forbs - and in one case we found facilitative effects. Moreover, the forbs Aster and Linum were not disadvantaged by the effects of Bromus and Agropyron, respectively. Thus, under our experimental conditions, effects on native species were contingent on the identity of the invasive and/or soil properties specific to the site. To the best of our knowledge, our results provide the first experimental assessment of such invasive effects in a plant community context. Callaway et al. (2004b) assessed interference effects of Centaurea maculosa on a variety of natives, as mediated by soil biota present upon initial invasion by Centaurea, and also observed a pattern of marked "winners" and "losers" among native species, in interaction with the invasive species. These results suggest the existence of native species that are not directly or indirectly sensitive to interference effects of invasives mediated by soil microbiota. Moreover, Knevel et al (2004) found that soil microbiota associated with most native members of an invaded community had positive effects on an invasive grass, but that biota associated with one native grass had strong negative effects. These observations raise the question of whether these respectively 'insensitive' and 'inhospitable' native species could have a valuable role as 'nurse species' (Padilla and Pugnaire 2006) in initial stages of ecological restoration of soils that have been biotically altered by invasives. This prospect would hinge on whether these native species themselves modify soil microbiota so as to increase fitness of other natives that are more sensitive to invasive-modified soils.

Our finding of inter-invasive facilitation and strong invasive antagonism to natives suggests that both management of invasives and ecological restoration of invaded sites will need to focus on strategies for restoration of soils, and in particular soil microbiota that are beneficial to native species. In this context, we note that, under our experimental conditions, soil modification by invasive or native species quickly overwhelmed any effects of the vegetation that had previously occupied these soils. In our experiments, both native- and invasive-modification treatments were applied to soils from sites that were dominated by either native or invasive species at the time of soil collection. We found that almost all effects of previous vegetation were weak and non-significant. The implication is that, in these cases, the previous vegetation did not leave an abiotic "legacy" strong enough to resist the transformative effects of our conditioning treatments (although we subjected the soil to considerable disturbance in the process of establishing the experiments). Our results contrast with other observations that invasive species can cause effects on soils that continues for some time after removal of the invasive species (Corbin and D'Antonio 2004; Ehrenfeld 2004; Renz and Blank 2004). When such legacy effects occur, they may create substantial and persistent problems in management and restoration of invaded sites (Corbin and D'Antonio 2004).

Acknowledgements We thank K. Jacobson, J. Larson, and C. Orengo for assistance in field collections. A. Symstad, Q. Guo, L. Kinkel, P. Graham and two anonymous reviewers made helpful comments that improved the manuscript. Funding was provided by US Geological Survey and Northern Prairie Wildlife Research Center. We especially thank staff at Lostwood and Medicine Lake National Wildlife Refuges and Theodore Roosevelt National Park for their assistance and support. 


\section{Appendix 1}

Results of analyses of variance for effects of soil conditioning on each species

\begin{tabular}{|c|c|c|c|c|c|}
\hline Experiment & Response species & Source & Mean square & $F$ & $\operatorname{Pr}>F$ \\
\hline \multirow[t]{27}{*}{ Medicine Lake/Agropyron } & \multirow[t]{3}{*}{ Agropyron } & Soil conditioning & 0.00049440 & 5.54 & 0.0203 \\
\hline & & Treatment & 0.00096842 & 10.85 & 0.0013 \\
\hline & & Interaction & 0.00020445 & 2.29 & 0.1329 \\
\hline & \multirow[t]{3}{*}{ Bromus } & Soil conditioning & 0.00000128 & 0.01 & 0.938 \\
\hline & & Treatment & 0.00007999 & 0.38 & 0.5396 \\
\hline & & Interaction & 0.00246497 & 11.66 & 0.0009 \\
\hline & \multirow[t]{3}{*}{ Euphorbia } & Soil conditioning & 0.00000004 & 0 & 0.9875 \\
\hline & & Treatment & 0.00076107 & 4.48 & 0.0364 \\
\hline & & Interaction & 0.00000377 & 0.02 & 0.8819 \\
\hline & \multirow[t]{3}{*}{ Aster } & Soil conditioning & 0.00029840 & 8.39 & 0.0045 \\
\hline & & Treatment & 0.00099300 & 27.9 & $<.0001$ \\
\hline & & Interaction & 0.00016453 & 4.62 & 0.0336 \\
\hline & \multirow[t]{3}{*}{ Linum } & Soil conditioning & 0.00004298 & 3.17 & 0.0774 \\
\hline & & Treatment & 0.00039381 & 29.09 & $<.0001$ \\
\hline & & Interaction & 0.00002392 & 1.77 & 0.1864 \\
\hline & \multirow[t]{3}{*}{ Ratibida } & Soil conditioning & 0.00009160 & 13.24 & 0.0004 \\
\hline & & Treatment & 0.00048683 & 70.34 & $<.0001$ \\
\hline & & Interaction & 0.00008496 & 12.28 & 0.0006 \\
\hline & \multirow[t]{3}{*}{ Bouteloua } & Soil conditioning & 0.00006111 & 5.71 & 0.0184 \\
\hline & & Treatment & 0.00000959 & 0.9 & 0.3456 \\
\hline & & Interaction & 0.00001218 & 1.14 & 0.2881 \\
\hline & \multirow[t]{3}{*}{ Koeleria } & Soil conditioning & 0.00000181 & 0.73 & 0.3951 \\
\hline & & Treatment & 0.00000326 & 1.31 & 0.2544 \\
\hline & & Interaction & 0.00001254 & 5.05 & 0.0265 \\
\hline & \multirow[t]{3}{*}{ Stipa } & Soil conditioning & 0.00014542 & 3.26 & 0.0736 \\
\hline & & Treatment & 0.00041787 & 9.36 & 0.0027 \\
\hline & & Interaction & 0.00000509 & 0.11 & 0.7362 \\
\hline \multirow[t]{12}{*}{ Lostwood/Bromus } & \multirow[t]{3}{*}{ Agropyron } & Soil conditioning & 0.00016333 & 1.66 & 0.2 \\
\hline & & Treatment & 0.00041813 & 4.25 & 0.0414 \\
\hline & & Interaction & 0.00029367 & 2.99 & 0.0866 \\
\hline & \multirow[t]{3}{*}{ Bromus } & Soil conditioning & 0.00043065 & 1.72 & 0.1929 \\
\hline & & Treatment & 0.00011914 & 0.47 & 0.4923 \\
\hline & & Interaction & 0.00142065 & 5.66 & 0.019 \\
\hline & \multirow[t]{3}{*}{ Euphorbia } & Soil conditioning & 0.00031263 & 1.59 & 0.21 \\
\hline & & Treatment & 0.00140528 & 7.14 & 0.0086 \\
\hline & & Interaction & 0.00081556 & 4.14 & 0.044 \\
\hline & \multirow[t]{3}{*}{ Aster } & Soil conditioning & 0.00005827 & 1.28 & 0.26 \\
\hline & & Treatment & 0.00118365 & 26.02 & $<.0001$ \\
\hline & & Interaction & 0.00000507 & 0.11 & 0.7391 \\
\hline
\end{tabular}


Appendix 1 continued

\begin{tabular}{|c|c|c|c|c|c|}
\hline Experiment & Response species & Source & Mean square & $F$ & $\operatorname{Pr}>F$ \\
\hline \multirow{42}{*}{$\begin{array}{l}\text { Theodore } \\
\text { Roosevelt/Euphorbia }\end{array}$} & \multirow[t]{3}{*}{ Linum } & Soil conditioning & 0.00007858 & 5.62 & 0.0193 \\
\hline & & Treatment & 0.00034993 & 25.04 & $<.0001$ \\
\hline & & Interaction & 0.00001248 & 0.89 & 0.3465 \\
\hline & \multirow[t]{3}{*}{ Ratibida } & Soil conditioning & 0.00002835 & 8.85 & 0.0035 \\
\hline & & Treatment & 0.00021371 & 66.74 & $<.0001$ \\
\hline & & Interaction & 0.00000622 & 1.94 & 0.1662 \\
\hline & \multirow[t]{3}{*}{ Bouteloua } & Soil conditioning & 0.00001125 & 0.94 & 0.334 \\
\hline & & Treatment & 0.00000715 & 0.6 & 0.4409 \\
\hline & & Interaction & 0.00000196 & 0.16 & 0.6865 \\
\hline & \multirow[t]{3}{*}{ Koeleria } & Soil conditioning & 0.00002270 & 6.4 & 0.0127 \\
\hline & & Treatment & 0.00002003 & 5.65 & 0.0191 \\
\hline & & Interaction & 0.00000230 & 0.65 & 0.4222 \\
\hline & \multirow[t]{3}{*}{ Stipa } & Soil conditioning & 0.00004693 & 0.9 & 0.3437 \\
\hline & & Treatment & 0.00033516 & 6.45 & 0.0124 \\
\hline & & Interaction & 0.00000281 & 0.05 & 0.8163 \\
\hline & \multirow[t]{3}{*}{ Agropyron } & Soil conditioning & 0.00005499 & 0.52 & 0.4721 \\
\hline & & Treatment & 0.00237143 & 22.44 & $<.0001$ \\
\hline & & Interaction & 0.00085065 & 8.05 & 0.0054 \\
\hline & \multirow[t]{3}{*}{ Bromus } & Soil conditioning & 0.00071707 & 2.16 & 0.1439 \\
\hline & & Treatment & 0.00486749 & 14.7 & 0.0002 \\
\hline & & Interaction & 0.00524837 & 15.85 & 0.0001 \\
\hline & \multirow[t]{3}{*}{ Euphorbia } & Soil conditioning & 0.00033496 & 0.97 & 0.3273 \\
\hline & & Treatment & 0.00045187 & 1.31 & 0.2555 \\
\hline & & Interaction & 0.00000344 & 0.01 & 0.9208 \\
\hline & \multirow[t]{3}{*}{ Aster } & Soil conditioning & 0.00110069 & 31.53 & $<.0001$ \\
\hline & & Treatment & 0.00092877 & 26.6 & $<.0001$ \\
\hline & & Interaction & 0.00082577 & 23.65 & $<.0001$ \\
\hline & \multirow[t]{3}{*}{ Linum } & Soil conditioning & 0.00005158 & 2.76 & 0.0996 \\
\hline & & Treatment & 0.00033666 & 17.98 & $<.0001$ \\
\hline & & Interaction & 0.00003835 & 2.05 & 0.155 \\
\hline & \multirow[t]{3}{*}{ Ratibida } & Soil conditioning & 0.00006078 & 10.01 & 0.002 \\
\hline & & Treatment & 0.00024850 & 40.93 & $<.0001$ \\
\hline & & Interaction & 0.00002765 & 4.55 & 0.0349 \\
\hline & \multirow[t]{3}{*}{ Bouteloua } & Soil conditioning & 0.00014836 & 11.65 & 0.0009 \\
\hline & & Treatment & 0.00003024 & 2.38 & 0.1259 \\
\hline & & Interaction & 0.00021046 & 16.53 & $<.0001$ \\
\hline & \multirow[t]{3}{*}{ Koeleria } & Soil conditioning & 0.00000882 & 1.6 & 0.208 \\
\hline & & Treatment & 0.00006765 & 12.29 & 0.0006 \\
\hline & & Interaction & 0.00001979 & 3.6 & 0.0604 \\
\hline & \multirow[t]{3}{*}{ Stipa } & Soil conditioning & 0.00009766 & 1.12 & 0.2911 \\
\hline & & Treatment & 0.00020286 & 2.34 & 0.1291 \\
\hline & & Interaction & 0.00023875 & 2.75 & 0.0999 \\
\hline
\end{tabular}

\footnotetext{
"Experiment" refers to the source of the soil and the invasive species that occupied the soil during the three conditioning cycles. The "Response species" is the species whose biomass was used as the response variable in the model. Soil conditioning refers to effects attributed to the species that had conditioned the soil; treatment refers to whether the soil had been pasteurized or not. In each case, denominator degrees of freedom $=118$
} 


\section{References}

Agrawal AA, Kotanen PM, Mitchell CE, Power AG, Godsoe W, Klironomos J (2005) Enemy release? An experiment with congeneric plant pairs and diverse above- and belowground enemies. Ecology 86:2979-2989

Bakker JD, Christian J, Wilson SD, Waddington J (1997) Seeding blue grama in old crested wheatgrass fields in southwestern Saskatchewan. J Range Manage 50:156-159

Bertness MD, Callaway RM (1994) Positive interactions in communities. Trends Ecol Evol 9:191-193

Bever JD (1994) Feedback between plants and their soil communities in an old field community. Ecology 75:1965-1977

Bever JD (2002) Host-specificity of AM fungal population growth rates can generate feedback on plant growth. Plant Soil 244:281-290

Blankespoor GW, May JK (1996) Alien smooth brome (Bromus inermis Leyss) in a tallgrass prairie remnant: seed bank, seedling establishment, and growth dynamics. Nat Area J 16:289-294

Bray SR, Kitajima K, Sylvia DM (2003) Mycorrhizae differentially alter growth, physiology, and competitive ability of an invasive shrub. Ecol Appl 13:565-574

Butler JL, Parker MS et al (2006) "Efficacy of flea beetle control of leafy spurge in Montana and South Dakota. Rangeland Ecol Manage 59:453-461

Caesar A (2005) Melding ecology, classical weed biocontrol, and plant microbial ecology can inform improved practices in controlling invasive plant species. Biol Control 35:240-246

Callaway R, Mahall B, Wicks C, Pankey J, Zabinski C (2003) Soil fungi and the effects of an invasive forb on grasses: neighbor identity matters. Ecology 84:129-135

Callaway RM, Thelen GC, Barth S, Ramsey PW, Gannon JE (2004a) Soil fungi alter interactions between the invader Centaurea maculosa and North American natives. Ecology 85:1062-1071

Callaway RM, Thelen GC, Rodriguez A, Holben WE (2004b) Soil biota and exotic plant invasion. Nature 427:731-733

Carino D, Daehler C (2002) Can inconspicuous legumes facilitate alien grass invasions? Partridge peas and fountain grass in Hawaii. Ecography 25:33-41

Christian JM, Wilson SD (1999) Long-term ecosystem impacts of an introduced grass in the Northern Great Plains. Ecology 80:2397-2407

Corbin JD, D'Antonio CM (2004) Effects of exotic species on soil nitrogen cycling: implications for restoration. Weed Technol 18:1464-1467

Cuddington K, Hastings A (2004) Invasive engineers. Ecol Model 178:335-347

Duda JJ, Freeman DC, Emlen JM, Belnap J, Kitchen SG, Zak JC, Sobek E, Tracy M, Montante J (2003) Differences in native soil ecology associated with invasion of the exotic annual chenopod, Halogeton glomeratus. Biol Fertil Soils 38:72-77

Ehrenfeld JG (2003) Effects of exotic plant invasions on soil nutrient cycling processes. Ecosystems 6:503-523

Ehrenfeld JG (2004) Implications of invasive species for belowground community and nutrient. Weed Technol 18:1232-1235
Eppstein MJ, Molofsky J (2007) Invasiveness in plant communities with feedbacks. Ecol Lett 10:253-263

Grilz PL, Romo JT (1995) Management considerations for controlling smooth brome on fescue prairie. Nat Area J 15:148-156

Haubensak KA, D'Antonio CM, Alexander J (2004) Effects of nitrogen-fixing shrubs in Washington and coastal California. Weed Technol 18:1475-1479

Hawkes CV, Belnap J, D’Antonio C, Firestone MK (2006) Arbuscular mycorrhizal assemblages in native plant roots change in the presence of invasive exotic grasses. Plant Soil 281:2369

Hawkes CV, Wren IF, Herman DJ, Firestone MK (2005) Plant invasion alters nitrogen cycling by modifying the soil nitrifying community. Ecol Lett 8:976-985

Hallett SG (2006) Dislocation from coevolved relationships: a unifying theory for plant invasion and naturalization? Weed Sci 54:282-290

Heidinga L, Wilson SD (2002) The impact of an invading alien grass (Agropyron cristatum) on species turnover in native prairie. Divers Distrib 8:249-258

Henderson DC, Naeth MA (2005) Multi-scale impacts of crested wheatgrass invasion in mixed-grass prairie. Biol Invasions 7:639-650

Kareiva P (1996) Developing a predictive ecology for nonindigenous species and ecological invasions. Ecology $77: 1651-1652$

Klironomos JN (2002) Feedback with soil biota contributes to plant rarity and invasiveness in communities. Nature 6884:67-69

Knevel IC, Lans T, Menting FBJ, Hertling UM, van der Putten WH (2004) Release from native root herbivores and biotic resistance by soil pathogens in a new habitat both affect the alien ammophila arenaria in South Africa. Oecologia 141:502-510

Kourtev P, Ehrenfeld J, Häggblom M (2002a) Exotic plant species alter the microbial community structure and function in the soil. Ecology 83:3152-3166

Kourtev P, Ehrenfeld J, Häggblom M (2003) Experimental analysis of the effect of exotic and native plant species on the structure and function of soil microbial communities. Soil Biol Biochem 35:895-905

Kourtev PS, Ehrenfeld JG, Huang WZ (2002b) Enzyme activities during litter decomposition of two exotic and two native plant species in hardwood forests of New Jersey. Soil Biol Biochem 34:1207-1218

Larson DL, Anderson PJ, Newton W (2001) Alien plant invasion in mixed-grass prairie: effects of vegetation type and anthropogenic disturbance. Ecol Appl 11:128-141

Lortie CJ, Brooker RW, Choler P, Kikvidze Z, Michalet R, Pugnaire FI, Callaway RM (2004) Rethinking plant community theory. Oikos 107:433-438

Marler MJ, Zabinski CA, Callaway RM (1999) Mycorrhizae indirectly enhance competitive effects of an invasive forb on a native bunchgrass. Ecology 80:1180-1186

Mitchell CE, Power AG (2003) Release of invasive plants from fungal and viral pathogens. Nature 421:625-627

Mummey DL, Rillig MC (2006) The invasive plant species Centaurea maculosa alters arbuscular mycorrhizal fungal communities in the field. Plant Soil 288:81-90 
Nernberg D, Dale MRT (1997) Competition of five native prairie grasses with Bromus inermis under three moisture regimes. Can J Bot 75:2140-2145

Ortega YK, Pearson DE (2005) Weak vs. strong invaders of natural plant communities: assessing invasibility and impact. Ecol Appl 15:651-661

Padilla FM, Pugnaire FI (2006) The role of nurse plants in the restoration of degraded environments. Front Ecol Environ 4:196-202

Pywell RF, Bullock JM, Hopkins A, Walker KJ, Sparks TH, Burke MJW, Peel S (2002) Restoration of species-rich grassland on arable land: assessing the limiting processes using a multi-site experiment. J Appl Ecol 39:294-309

Reynolds HL, Packer A, Bever JD, Clay K (2003) Grassroots ecology: plant-microbe-soil interactions as drivers of plant community structure and dynamics. Ecology 84:22812229

Reinhart KO, Callaway RM (2006) Soil biota and invasive plants. New Phytol 170:445-457

Rejmanek M, Richardson DM (1996) What attributes make some plant species more invasive? Ecology 77:1655-1661

Renz MJ, Blank RR (2004) Influence of perennial pepperweed (Lepidium latifolium) biology and plant-soil relationships on management and restoration. Weed Technol 18:13591363

Richardson DM, Allsopp N, D'Antonio CM, Milton SJ, Rejmanek M (2000) Plant invasions - the role of mutualisms. Biol Rev Camb Philos Soc 75:65-93

Saggar S, McIntosh P, Hedley C, Knicker H (1999) Changes in soil microbial biomass, metabolic quotient and organic matter turnover under Hieracium pilosella L. Biol Fertil Soils 30:232-238

SAS Institute Inc. (1999) SAS OnlineDoc ${ }^{\circledR}$, version 8. In SAS Institute Inc., Cary, NC

Scott N, Saggar S, McIntosh P (2001) Biogeochemical impact of Hieracium invasion in New Zealand's grazed tussock grasslands: sustainability implications. Ecol Appl 11:1311-1322

Shea K, Chesson P (2002) Community ecology theory as a framework for biological invasions. Trends Ecol Evol 17:170-176

Simberloff D, Gibbons L (2004) Now you see them, now you don't - population crashes of established introduced species. Biol Invasions 6:161-172
Simberloff D (2006) Invasional meltdown 6 years later: important phenomenon, unfortunate metaphor, or both? Ecol Lett 9:912-919

Stanton ML (2003) Interacting guilds: moving beyond the pairwise perspective on mutualisms. Am Nat 162:S10-S23

Symstad A (2004) Secondary invasion following the reduction of Coronilla varia (crownvetch) in sand prairie. Am Midl Nat 152:183-189

Trammell MA, Butler JL (1995) Effects of exotic plants on native ungulate use of habitat. J Wildl Manage 59:808816

van der Heijden MGA (2004) Arbuscular mycorrhizal fungi as support systems for seedling establishment in grassland. Ecol Lett 7:293-303

van der Putten WH (2003) Plant defence belowground and spatiotemporal processes in natural vegetation. Ecology 84:2269-2280

van der Putten WH, Yeates GW, Duyts H, Reis CS, Karssen G (2005) Invasive plants and their escape from root herbivory: a worldwide comparison of the root-feeding nematode communities of the dune grass Ammophila arenaria in natural and introduced ranges. Biol Invasions 7:733-746

Vitousek PM, Walker LR (1989) Biological invasion by Myrica faya in Hawaii: plant demography, nitrogen fixation, ecosystem effects. Ecol Monogr 59:247-265

Walker KJ, Stevens PA, Stevens DP, Mountford JO, Manchester SJ, Pywell RF (2004) The restoration and re-creation of species-rich lowland grassland on land formerly managed for intensive agriculture in the UK. Biol Conserv 119:1-18

Westover KM, Kennedy AC, Kelley SE (1997) Patterns of rhizosphere microbial community structure associated with co-occurring plant species. J Ecol 85:863-873

Wilson GWT, Hartnett DC (1998) Interspecific variation in plant responses to mycorrhizal colonization in tallgrass prairie. Am J Bot 85:1732-1738

Wolfe BE, Klironomos JN (2005) Breaking new ground: soil communities and exotic plant invasion. Bioscience 55:477-487

Yu XJ, Yu D, Lu ZJ, Ma KP (2005) A new mechanism of invader success: exotic plant inhibits natural vegetation restoration by changing soil microbe community. Chin Sci Bull 50:1105-1112 